\title{
THE DEVELOPMENT OF PROBLEM-BASED PSYCHOTROPIC AND ADDICTIVE SUBSTANCE LEARNING KITS TO IMPROVE THE STUDENTS' METACOGNITION
}

\author{
Nur Hanifah', Saiful Ridlo ${ }^{2}$, dan Lisdiana ${ }^{2}$ \\ ${ }^{1}$ Program of Natural Sciences Education, State University of Semarang \\ ${ }^{2}$ Faculty of Mathematics and Natural Sciences, State University of Semarang \\ E-mail: nurhanifah8388@gmail.com
}

\begin{abstract}
This study was aimed to develop problem-based psychotropic and addictive substance learning kits to improve the students' metacognition and concept mastery. The kits were developed in three stages (define, design, develop). The "develop" stage used the non-equivalent control group design. The subjects were grade VIII students of SMP Nasima, Semarang. The findings of the study showed that the developed learning kits were valid in the very good category. The mastery of concepts and metacognition improved with an average percentage of $\mathrm{N}$-gain for the experimental group with the high category. The result of the questionnaires on metacognition showed the $\mathrm{N}$-gain percentage of the experimental group belonging to the fair category. The students' ability to solve problems and the implementation in the small class and in the experimental group in the first and fourth meetings were in the good category. The students and teacher gave positive responses to the developed learning kits and its implementation in the class. The findings showed that the problem-based learning can be used for improving students' metacognition.
\end{abstract}

Keywords: Problem-based learning, metacognition, addictive and psychotropicsubstances

\section{PENGEMBANGAN PERANGKAT PEMBELAJARAN ZAT ADIKTIF DAN PSIKOTROPIKA BERBASIS MASALAH UNTUK MENINGKATKAN METAKOGNISI SISWA}

\begin{abstract}
Abstrak: Tujuan penelitian ini adalah menghasilkan perangkat pembelajaran zat adiktif dan psikotropika berbasis masalah yang teruji mampu meningkatkan metakognisi dan penguasaan konsep siswa. Pengembangan perangkat pembelajaran menggunakan tiga langkah pengembangan (define, design, develop). Tahap develop menggunakan desain Non equivalent Control Group Design. Subjek penelitian adalah siswa kelas VIII SMP Nasima Semarang. Hasil penelitian menunjukkan bahwa perangkat pembelajaran yang dikembangkan valid dengan kategori sangat baik. Penguasaan konsep dan metakognisi mengalami peningkatan rata-rata persentase $\mathrm{N}$-gain kelas eksperimen dengan kategori tinggi. Hasil kuesioner metakognisi menunjukkan persentase $\mathrm{N}$-gain pada kelas eksperimen dengan kategori sedang. Kemampuan pemecahan masalah dan keterlaksanaan pembelajaran pada siswa kelas kecil dan kelas eksperimen pada pertemuan ke-1 sampai ke-4 dengan kategori baik. Siswa dan guru memberikan respon positif terhadap perangkat pembelajaran yang dikembangkan dan penerapannya di dalam kelas. Hasil penelitian menunjukkan bahwa pembelajaran berbasis masalah dapat digunakan untuk meningkatkan metakognisi siswa.
\end{abstract}

Kata Kunci: pembelajaran berbasis masalah, metakognisi, zat adiktif dan psikotropika

\section{INTRODUCTION}

The aim of education ispreparing a person to become perfect Indonesian human and be responsible for his or her life in accordance with the 4 Pillars of Education according to UNESCO
(Beelen and Dhert, 2010) which consists of learning to know, learning to do, learning to live together, and learning to be. Implicitly, learning to know means to learn throughout the life (lifelong education) and learn how to learn. In the process 
of learning to know,it is not only to know what is meaningful but also to know what is not beneficial for life, so that students become independent learners.

Natural sciences education is directed to find out and to do so that it can help the students to gain a deeper understanding about their surroundings. In fact, natural sciences consists of four main elements, namely attitudes, processes, products and applications. The four elements in the process of learning science are expected to emerge, so that students can learn from the experience of the learning process as a whole and ultimately the purpose of natural sciences education as well as general educational goals can be achieved.

The reality shows that the implementation of natural sciences lessons at Nasima Junior High Schoolwas overcrowded with material and information especially on the psychotropic and addictive substance material, so that the students are only able to understand someknowledge. The learning process is focused on making the students master the information by rote memory. The learning process of learning to know just covers the "knowing", making the problems that were presented merely academic (book oriented) and not refer to contextual issues. The students' cognitive learning achievement is still the major concern for measuring the quality of education and the learning process.

The psychotropic and addictive substance material demands the students to describe the nature or the effect of psychotropic and addictive substances. It also makes the students able to prevent themselves fromtheir negative effects. There are many problems in life related to the psychotropic and addictive substancesand their abuse. Based on theoccurring problems, the students are expected to comprehensively understand the psychotropic and addictive substance material. Then, they are expectedto be able to apply the learning outcomes in the form of the selection of the right attitude if faced with problems related to the abuse of psychotropic and addictive substances.

Warouw (2009) stated that the teachers do not know the importance of empowering metacognition in learning. The learning that can empower the students' potential such as the empowerment of metacognition thoughthas not been empowered deliberately in the learning process (Haryani, 2011). As a result, the learning process becomes less meaningful. Such learning patterns cause the students to join the lessons because of the obligation or necessity rather than their interest in the lesson. As a result, the students are not trained to be independent and their independence does not develop. The expectation that the students can become independent learners is still far from reality.

Metacognition is an important thing in education, Flavell in Perfect and Schwartz (2003) suggested a good school should be an ideal place for the development of metacognition because self-awareness learning took place there so that the school becomes an excellent school. Kipnis and Hofstein (2007) revealsthat metacognition is considered as an important component in learning science because it encourages students to be independent and enhances understanding in learning. Therefore, teachers need to train and develop students' metacognition by accustoming students to learning to solve problems. Problembased learning is one of the learning approaches that is used to stimulate a high level of student thinking skill in situations oriented on the issue of the real world, including learning how to learn (Ibrahim and Nur, 2005).

Based on the explanation, there is a need for research and development of the problembased learning kits on the psychotropic and addictive substance that can improve students' metacognition. The problem-based learning kits were developed tosupport learning. The learning kits refer to the contextual issues that become expected to be meaningful learning and can empower metacognition thinkinghoughtdelibe in learning.

Based on the identification of the problems, three research problems can be formulated. First, how is the characteristics of problem-based psychotropicandaddictive substance learning kits oriented on improving metacognition? Second, aredeveloped the problem-based psychotropicandaddictive substance learning kitsvalid, effective and practical? Third, what is the influence of the problem-based psychotropic 
and addictive substance learning kits on students' metacognition and mastery of concepts? The development research of problem-based learning equipment aims to producetestedpsychotropic and addictive substance learning kits which were able to improve students' metacognition and mastery of concepts.

\section{METHOD}

\section{Development Procedure} follows.

In detail the steps of the research are as

Defining stage. The literature study was conducted: to review the findings of the research that has been done, to analyze the standard of competencies, basic competencies, indicators, and toanalyze the psychotropic and addictive substance concepts and metacognition indicators. The field study was conducted to gather information and identify the real situation of learning and students' characteristics.

Designing Stage. The stage of the learning kit design was based on the initial study results i.e. creating problem-based learning kits oriented to enhance metacognition organized as a syllabus, a lesson plan, materials, an evaluation instrument, self-assessment questionnaires, and students' responsequestionnaires. The product is referred to as Draft 1.

Developing stage. The activities in this developing stage include the expert's validation, test questions, limited trial and field testing. As the explanation of this stage is as follows.

The expert's validation. The expert's validation was done to obtain suggestions for improvement and assess the design of the learning (Draft 1). Based on the expert's validation result, a revision of the learning kits and instrument was conducted to produce Draft 2. Validation of learning kits and instrument was focused on content, format, language, illustration and compatibility with the problem-based learning and metacognition oriented.

A validation test was conducted to determine validity and reliability of the pre-test and the posttest that would be used by the students on the stage of field testing. The limited trial was done for the reflection ofthe validated learning kits(Draft 2).
The simulation results of the limited trialin the class would be analyzed and would be used for revising the learning kits that wouldbe used in the filed testing (Draft 3).

Draft 3 was tested in the test class, starting with a pre-test and ending with a post-test. At the end of the meeting, the students would also be given the questionnaires to know their response toward the use of the developed learning kits. During the implementation of the teaching and learning process, the researchers accompanied by observers observed the learning process. After the teaching and learning activities, the researchers and observers did a reflection on the learning activities that had been implemented. The reflection result wasused as the basis for the revision of the learning kits. The research design on the developing stage wasthe Nonequivalent Control Group Design (Sugiyono, 2010). The research design is presented in Figure 1. The difference between the initial test and the end of the test was assumed as the effects of the treatment and measured with $\mathrm{N}$-gain test.

$$
\frac{\mathrm{O} 1 \mathrm{X} \mathrm{O} 2}{\mathrm{O} 3 \mathrm{O} 4}
$$

\section{Figure 1. Research Design}

Description:

O1, O3: pre-test

O2, O4: post-test

$\mathrm{X}$ : problem-based psychotropic and addictive substance learning

The trial in this research was performed twice, namely limited testing and the field testing. The limited testing was aimed to validate the learning kits. The subject of this research was the eighth grade students of Nasima Junior High School Semarang in the academic year of 2012/2013 consisting of 10 students taken randomly from VIII B. The field testing used VIII $\mathrm{A}$ as the experiment class and VIII $\mathrm{C}$ as the control class, with each class consisting of 28 students. The subject of limited testing and the experiment class in the field testing got the same treatment, namely a pre-test, the implementation of problem-based learning and a post-test. 


\section{FINDINGS}

The findings of the defining stage

The information obtained from the preliminary research phase then was analyzed and the result was as follows.

An analysis of the curriculum and natural sciences lessons at NasimaJunior High School Semarang

Natural sciences lessons at Nasima Junior High School Semarang refers to the School-based curriculum with the competency standard and basic competencies presented separately between physics, chemistry and biology. The psychotropic and addictive substance material inthe natural sciences lesson at Nasima Junior High School are still submitted in monotonous and teacher oriented.

An analysis of the characteristics of students

The information obtained from the analysis of the characteristics of students was that the eighth grade students of Nasima Junior High Semarang in the academic year of 2012/2013 were divided into four classes with the an average of 28 students in each class. These students were heterogeneous in cognitive problems. The result of the observation and the interview with the eighth grade natural sciences teacher of Nasima Junior High Semarang was as follows.

1) The students have high enough academic ability compared with students in other junior high schools in Semarang.

2) The students are less excited in learning biology. This can be seen from their learning activity. They were just quiet. They just sat and listened to the teacher.

3) The students are less involved in the learning activities so that they were not trained to be independent.

An analysis of the structure of the contents

Analysis of the structure of the contents aimed to identify the main material learned by the students. Based on the curriculum of Nasima Junior High School Semarang, the following result was obtained.

1) Standard of competencies (SK):

Understanding the usefulness of chemical materials in life
2) Basic competencies $(\mathrm{KD})$ :

a. Describing the nature/effect of the psychotropic and addictive substances

b. Preventing themselves from the effect of the psychotropic and addictive substances

3) Material

a. Psychotropic and addictive substances

b. How to prevent them from the effect of psychotropic and addictive substances

Task Analysis

A task analysis was done by examining the tasks in accordance with the competency standard and basic competencies which was further elaborated into the indicators. Some given tasks included online library studies, discussions, presentations, observation of the environment, the field studies, making the outline of the result of the discussions, reporting the results of the field study and writing essays through social networking sites.

An analysis of learning objectives

The formulation of learning objectives was carried out to formulate learning goals based on the analysis of the task and the analysis of the material so that it could become more operational and reveal the behaviors that could be observed. A series of learning objectives were listed on the teaching materials and used as the basis for designing the learning kits.

\section{The findings of the designing stage}

The characteristics of learning kits designed in this research were as follows.

Syllabus. The syllabus was designed out with reference to the problem-based learning, and school-based-curriculum-oriented on the improvement of metacognition.

Lesson Plan. The lesson plan was made by referring to the problem-based learning, and school-based-curriculum-orientedon the improvement of metacognition. The lesson plan was designed for four times. The discussed topics in the four meetings were as follows.

1) The addictive substances (cigarettes, coffee, alcohol, and inhalant).

2) Psychotropic substances and narcotics. 
3) The negative effects of the use of addictive substance, narcotics and psychotropic substances.

4) How to prevent themselves from the effect of addictive substance, narcotics and psychotropic substances.

Materials. The materials in this research were in the form of a book containing material derived from the relevant learning materials and controversial articles about psychotropic and addictive substances, a science corner in the form of a collection of information expected to strengthen students' mastery of concepts and equipped with self-assessing as a part of the metacognitive strategy, worksheets in the form of an analysis of the problems of psychotropic and addictive substances that had to be discussed by the students in the class, the observation sheet of the environment, mind-map related to the learning material recently learned and a reflective journal that would be filled by the students based on the learning process in the class.

Evaluation instrument. An evaluation instrument in this research was in the form of a concept test using metacognition indicators in the form of explanation 10 point questions. This evaluation instrument was used to know the level of the mastery of concepts that formed the basis of the determination of the learning level and the improvement of students' metacognition during the lesson.

The questionnaires of metacognition. The questionnaires of metacognition aimed to know the improvement of the metacognition before and after the lesson. The questionnaires was made based on the indicators of metacognition developed by Haryani (2011) and indicators of Science Students', Self-Efficacy Metacognition and learning processes: The SEMLI-S by Thomasa, Andersonb and Nashonb (2008). The questionnaires of metacognition in this research contained 11 metacognition indicators which consisted of 50 statements.

Troubleshooting observation sheet.A troubleshootingobservation sheet aimed to know the troubleshooting capabilities of students in learning. The aspect that was observed in the troubleshooting observation sheet in research consisted of 10 points of observation.
The questionnaires of students'response. The questionnaires of students' response aimed to know the response of the students to the problembased learning. The questionnaires of students' response in this research contained 19 statements about applied learning of the psychotropic and addictive substances.

The observation sheet of learning implementation. The observation sheet aimed to provide an assessment of the teaching syntax implementation using the problem-based psychotropic and addictive substance learning kits that was oriented to the improvement of the metacognition. The observation sheet contained 33 aspects that were assessed by the two observers.

\section{The Results of the Development Stage The validation result of the learning kits}

Validated learning kits are in the form of the syllabus, a lesson plan, learning materials, an evaluation instrument, the questionnaires of metacognition, a troubleshooting observation sheet, the questionnaires of students' response, and the observation sheet of learning implementation. The validators of the learning kits were three Postgraduate lecturers of State University of Semarang. The result of the validation was that the learning kits could be used with little revision. Assessment of the validator stated that the validity of learning kits obtain avery valid average score category for the entire learning kits developed.

Table 1. Recapitulation of the validation results of learning kits

\begin{tabular}{lcc}
\hline \multicolumn{1}{c}{ Type of equipment } & Value & Category \\
\hline Syllabus & 4.35 & Very valid \\
Lesson plan & 4.5 & Very valid \\
Learning Materials & 4.5 & Very valid \\
Evaluation instruments & 4.6 & Very valid \\
$\begin{array}{l}\text { The questionnaire of } \\
\text { metacognition }\end{array}$ & 4.5 & Very valid \\
$\begin{array}{l}\text { Troubleshooting observation } \\
\text { sheet }\end{array}$ & 4.4 & Very valid \\
$\begin{array}{l}\text { The questionnaire of students' } \\
\text { response }\end{array}$ & 4.8 & Very valid \\
$\begin{array}{l}\text { The observation sheet of } \\
\text { learning implementation }\end{array}$ & 4.6 & Very valid \\
\hline
\end{tabular}




\section{An analysis result of the concept mastery and metacognition}

Students' concepts mastery and metacognition as the measeured aspects of research and development of the problem-based psychotropic and addictive substances changed due to the implementation of problem-based learning. The recapitulation result of the pre-test and the post-test can be seen in Table 2 .

Table 2. Recapitulation of the value of the pretest and the post-test

\begin{tabular}{|c|c|c|}
\hline The variables & $\begin{array}{c}\text { The } \\
\text { Control } \\
\text { Class } \\
\mathrm{N}=28\end{array}$ & $\begin{array}{c}\text { The } \\
\text { Experiment } \\
\text { Class } \\
\mathrm{N}=28\end{array}$ \\
\hline \multicolumn{3}{|l|}{ Pre-test } \\
\hline The average of pre-test & 22 & 18 \\
\hline The highest value of pre-test & 34 & 37 \\
\hline $\begin{array}{l}\text { The lowest value of the pre- } \\
\text { test }\end{array}$ & 7 & 8 \\
\hline Completed & 0 & 0 \\
\hline \multicolumn{3}{|l|}{ Post-test } \\
\hline The average post-test & 75 & 84 \\
\hline $\begin{array}{l}\text { The highest value of post- } \\
\text { test }\end{array}$ & 97 & 98 \\
\hline The lowest value of post-test & 50 & 60 \\
\hline Completed & 16 & 26 \\
\hline
\end{tabular}

It can be noted that the average score of the pre-test of the control class and the experiment class was still under the assigned minimum mastery level (KKM), that is 74 . The experiment class had better scores than the control class. The score data of pre-test and the post-test on the control class and the experiment class were analyzed using the test of normality, homogeneity, and $\mathrm{T}$ test. The recapitulation of the test results can be seen in Table 3 .

Table 3. The recapitulation of result test of homogeneity, normality and $T$ tests in Control and Experiments Class

\begin{tabular}{|c|c|c|c|}
\hline Test & Pre- & $\begin{array}{l}\text { Post- } \\
\text { test }\end{array}$ & $\mathrm{N}$-gain \\
\hline Normality Test Control & 0.200 & 0.200 & 0.200 \\
\hline Experiment & 0.200 & 0.112 & 0.200 \\
\hline $\begin{array}{l}\text { Homogeneity } \\
\text { Test }\end{array}$ & 0.866 & 0.120 & 0.075 \\
\hline $\mathrm{T}$ test & 0.270 & 0.007 & 0.001 \\
\hline
\end{tabular}

The results of the pre-test on the control and the experiment class after the homogeneity test obtained a significance level of 0.866. So, the samples of the pre-testwere homogeneous. Meanwhile, the normality test showed significance at the level of 0.200 and it showed normal data distribution. Since the data of the pre-test were homogeneous and had normal distribution, then it was proceeded with the $t$ test resulted in the significance level of 0.270 .This means that the pre-test data do not havean obvious difference. Hence, the control and experiment classes had homogenous academic ability and characteristics.

The results of the post-test on the control and experiment class after the homogeneity testobtained a significance level of 0.120 . So,the samples of the post-testwere homogeneous. Meanwhile, the normality test indicateda significance level of 0.200 and the data had normal distribution. Because the results of the post-test were homogeneous and the data had normal distribution, then it was continued with the $t$ test with a significance level of 0.007 , so the post-test data had a clear difference.

Based on the results of the pre-test and the post-test in the small classes, the control class and experiment classes obtained the value of $\mathrm{N}$-gain. The $\mathrm{N}$-gain was used as a reference to see the effectiveness of using the psychotropic and addictive substance problem-based learning kits that were developed towards concepts mastery and students' metacognition. The comparison of the $\mathrm{N}$-gain average between the control and experiment classes can be seen in Table 4. The value of $\mathrm{N}$-gain control and experiment classes after the homogeneity test reached a significance level of 0.075 . So, the standard gain from the samples was homogeneous. Meanwhile, the normality test showed a significance level of 0.200 and so the data had normal distribution. Then it was continued with thet test. The result showeda significance level of 0.001 , and because the significance level was less than 0.05 , the standard gain of data had a real difference. It could be concluded that there was a real difference in the implementation of the problem-based psychotropic and addictive substance learning kits between the control and experiment classes. 
Table 4. Comparison of the average N-gain of extensive test

\begin{tabular}{lcc}
\hline \multicolumn{1}{c}{ Trial Class } & N-gain $(\%)$ & Description \\
\hline Control Class & 69 & Medium \\
Experiment Class & 81 & High \\
\hline
\end{tabular}

Based on Table 4, it can be seen that the average of $\mathrm{N}$-gain measured improvement of concepts mastery and students' metacognition in the control group was lower thanthat in the experiment group. The enhancing ability of students' metacognition in the experiment class according to the sequence of $\mathrm{N}$-gain each metacognitions' indicator was applying the understanding on the new situation, identifying information, finding out about what and how, and elaborating information.

Problem-based psychotropic and addictive substance learning kits that aimed to improve students' metacognition had an advantage, namely the existence of self-assessing on learning by the students. The students were trained to develop the thinking process regularly to know the concepts that had been mastered during the learning, what was not yet known and how to develop knowledge that had been learned. Warrouw (2009) stated that the learning control process allowed students to become independent learners so the concepts that had known wouldbe leearned continually.

Through the problem-solving process from the problem-based students' worksheet in the lesson materials, students could understand the content of learned material. The problem-based worksheet was an open-ended problem related to the reality or daily life. It is in accordance with the opinion of Graaff and Kolmos (2003), Tan (2004), Woods (2005), Jonassen and Hung (2008) who stated that the students are given a problem as a starting point as a real problem which was close to the students' life, so the students could practice to resolve the problem by finding the required information and learning new knowledge.

Schneider (2008), Shannon and College (2008), Susantini (2009), Okoro and Chukwudi (2011), Zohar and Dori (2012) stated metacognition helped learners become more independent, able to organize themselves to achieve the goal consciously and deliberately to meet their intellectual needs. Students who had the skill in assessing their own metacognitive and who were conscious about their ability to think play more strategically and better than those who do not realizeabout the ability of their mentality system in solving problems. Thus, teachers need to help students to be aware of their characteristics of the cognitive ability.

The importance of problem solving and metacognition was identified as a key factor in the process of problem solving. Neunhaus et al. (2011) stated there were two metacognitive skills which were important in problem-solving, that is, self monitoring and planning. Self monitoring refers to the individual's ability to check directly from the process of problem solving. Planning involves a complex problem solving into subcategories so that the goals can be solved separately and sequentially to enrich the final settlement.

Haribhai (2012) stated that metacognition refers to cognitive, if metacognition is understood as knowledge about one set of self instructions to regulate the performance of tasks, so cognition is the instruction vehicle itself. Cognitive activities are in turn to metacognition, for example monitoring and evaluation. Metacognition can be observed in the self instructions which are spoken by students but not always explicitly, can be heard or seen during the performance of tasks and also can be deduced from certain cognitive activities, such as doing step by step in the form of planned behaviour.

When the students are able to design, monitor, and reflect their learning process consciously, they will become more confident and independent in learning. The independence of student learning is the basic capital to fulfill their intellectual needs. The teachers' role is developing the students' metacognitive ability as a learner. Larkin (2006) stated metacognition is developing along with growing older and it is influenced by exercise, too. Philippou and Panaoura (2004) also stated that the development of metacognition is notan automatic process, but the result of a long development process of the cognitive system. The interaction of one another can provide a stimulus that is required by individuals to become more aware of their cognitive process. 


\section{Results of metacognitions' questionnaires}

The questionnaires of metacognition in this research was used to know the improvement of metacognition before and after joining problembased psychotropic and addictive substance learning. The questionnaires were intended to support the measurement of metacognition in the form of a test. The recapitulation data of $\mathrm{N}$-gain calculation of metacognitions' questionnaires to control and experiment classes are presented in Table 5. Based on Table 5, it can be known that the N-gain of the metacognitions' questionnairesin the control class belonged to the low category and that in the experiment class belonged to the medium category.

Table 5. The recapitulation of N-gain Extensive Test of Metacognitions'Questionnaires

\begin{tabular}{lcccc}
\hline Class & $\begin{array}{c}\text { Total } \\
\text { score } \\
\text { pre-test }\end{array}$ & $\begin{array}{c}\text { Total } \\
\text { score of } \\
\text { the post- } \\
\text { test }\end{array}$ & $\begin{array}{c}\text { N-gain } \\
(\%)\end{array}$ & Description \\
\hline $\begin{array}{l}\text { Control } \\
\text { Class }\end{array}$ & 3845 & 4117 & 15,26 & Low \\
$\begin{array}{l}\text { Experiment } \\
\text { Class }\end{array}$ & 3447 & 4302 & 40,45 & Medium \\
\hline
\end{tabular}

The measurement of the metacognition using the questionnaires or self-assessment was done by Panaoura and Philippou (2004), Susantini (2009), Warrow (2009) once. Based on the research result, it can be seen that the prominent metacognition indicator on the experiment class is the concentration control. The metacognition indicators that developed during the lesson were as stating a purpose; finding out about what, how and why; realizing that a given task requiree a lot of references; being aware of their own capabilities in performing tasks; identifying information; designing what would be learned; thinking of the intended purpose; elaborating information from various sources; knowing that the elaboration strategies improved understanding; thinking about how others think of tasks; assessing the achievement of objectives; applying the understanding in the new situation; analyzing complex problems; selecting the important information that was used in solving problems; and thinking of the way to think during the problem solving process.

\section{Observationresult of problem solving}

Assessment of students' ability in problem solving in learning was measured through the problem solving observation sheet. The problem solving capabilities in the experiment class in meetings 1-4 belonged to the good category and were experiencing an increasing percentage in each meeting. In general the problem-based learning was able to develop the communication skill between students in solving problems and developing cooperation between the students both ingroups or in one class. Bilgin, Senocak and Sozbilir (2009) stated that the problem-based learning helped students develop communication skills and cooperation, the skills which were used to access and utilize theobtained information.

\section{Observation result of the learning implemen- tation}

The results of the assessment for the learning implementation in the field testing (the experiment class) in meetings 1-4 belonged to the good category and were experiencing an increasing percentage in each meeting. Overall, in the problem-based learning implementation process, the teachers could do well the problembased learning syntax according to Arends (2004). In the phase of students' orientation to the problem, the teacher presented a contextual problem and actively motivated students to be engaged in the problem solving activities. In the students' organizing phase, the teacher divided the students in groups, and gave explanation about the things to note in conducting the investigation. In the mentoring phase of investigation groups, the teacher acted as a facilitator of the students in conducting the investigation and helped students who had difficulty during the investigation activities.

In the phase of development and product presentation, the teacher allowed the the students to present the results of their group discussions as well as facilitated and motivated students in the presentation. In the analysis and evaluation of the solving problemphase, the teacher motivated each group to be active in the class discussion, asked students to reveal the conclusion of the investigation results andto do class discussion in their own words. In the closing activities, the 
teacher was able to provide good reinforcement of the concepts and gave an opportunity to the students to ask questions.

\section{Result of students' response to the question- naires}

In general, the students responded positively to the problem-based psychotropic and addictive substance learning kits. This was related to the teachers' techniques and way in serving and packing learning materials to the students. Based on the results of students' response to the questionnaires, it can be seen that students had enthusiasm and high spirit to the developed learning so that students were more diligent in learning. The problem-based learning allowed students to be more confident in arguing and asking to get or find the concept. Positive responses of students to the problembased learning in this research were in accordance with the research results done by Liu et.al. (2011) stating that motivation and attitudes of students toward science improvedinthe problem-based learning.

\section{Result of the teachers' response}

The results of teachers' response to the questionnaires showed that the teachers gave positive responses to the problem-based psychotropic and addictive substance learning. According to the teacher, the problem-based learning was very impressive because students were faced with the real problem that motivated them to learn. The teacher said that with the problem-based learning, students used a variety of learning resources because teachers' role was as a facilitator not as an information giver.

From the interview result, it was also revealed about difficulties felt by the teachers in implementing problem-based psychotropic and addictive substance learning kits. The difficulties were that the students were unfamiliar with the problem-based learning so that it took a long time to organize the students to learn and the teachers were not quite familiar yet with metacognition and the learning types that could improve metacognition. This is in accordance with the study of Zohar and Barzillai (2013) which indicated that teachers still had insufficient knowledge about metacognition and its teaching method. In the implementation of the problembased learning, the problemsthat were faced by teachers included the problem of the learning time which mostly spent to organize the students to learn. This is in line with the opinion of Akinoglu and Tandogan (2006), Hernani (2010), Haryani (2011), Mambay (2011) that the implementation of problem-based learning required more time for teaching and well timearrangement.

\section{CONCLUSION}

Based on the results of the research and development of problem-based psychotropic and addictive substance learning kits, it can be summarized as follows.

1. The characteristics of problem-based psychotropic and addictive substance learning kits developed such as: (1) a problem that had to be solved or the solution had to be found by students, (2) student-centered learning independently in groups, (3) explored the scope of the problem based on the issues of learning which had been agreed within the groups, (4) learning made students do an investigation and prioritize on the responsibility and independence of the students in seeking information from various sources to solve problems, (5) students produced paper/products such as the formulation of the discussion result and the field study report that presented by representatives of students from each group, and (6) The students and teacher didthe self-reflection of learning.

2. The learning kits that were developed met the criteria of the validity, effectiveness, and practicality.

3. There is a difference result in the mastery of concepts and metacognition between the control and experiment classes.

\section{ACKNOWLEDGEMENT}

The gratitude of the author goes to the supervisor Dr. Saiful Ridlo, M.Si and dr. Lisdiana, M.Si who have been willing to provide feedback and motivation, and to Dr. Haryani, M.Pd, Dr. Suharto Linuwih, M,Si, and dr. R. Susanti, M.P who have validated the instrument. 


\section{BIBLIOGRAPHY}

Akinoglu, O. dan Tandogan, R.O. 2006. "Effects of Problem-Based Active Learning in Science Education on Students' Academic Achievement, Attitude and Concept Learning". Eurasia Journal of Mathematics, Science \& Technology Education, Volume 3 No. 1. Page 71-81.

Arends, R. I. 2004. Learning to Teach. $5^{\text {th }}$ Ed. Boston: McGraw Hill.

Bilgin, I., Senocak, E., dan Sozbilir, M. 2009. "The Effects of Problem-Based Learning Instruction on University Students' Performance of Conceptual and Quantitative Problems in Gas Concepts". Eurasia Journal of Mathematics, Science and Technology Education, Volume 5 No. 2. Page 153-164.

Beelen, J. dan Dhert, S. 2010. "UNESCO for Teacher Educators".Piec Papers, Volume 1 No.1. Page 65-77.

Graaff, E. D. dan Kolmos, A. 2003. “Characteristics of Problem Based Learning". International Journal Engineering Education, Volume 19 No. 5. Page 657-662.

Haryani, S. 2011. "Pengembangan Model Praktikum Kimia Analitik Instrumen Berbasis Masalah untuk Meningkatkan Metakognisi Mahasiswa Calon Guru". Disertasi. Bandung: Sekolah Pascasarjana UPI.

Haribhai, T. S. 2012. "Complex Relation Between Metacognition and Cognition". Paripex Indian Journal of Research, Volume 1 No.10. Hal 44-45.

Hernani. 2010. "Pembekalan Keterampilan Generik bagi Calon Guru Melalui Pembelajaran Berbasis Masalah yang Mengintegrasikan Perkuliahan dan Praktikum Kimia Analitik". Disertasi. Bandung: Sekolah Pascasarjana UPI.
Ibrahim, M. dan Nur, M. 2005. Pengajaran Berbasis Masalah. Surabaya: University Press.

Jonassen, D. H. dan Hung, W. 2008. “All Program are not Equal: Implications for Problem Based Learning". Interdisciplinary Journal of Problem Based Learning, Volume 2 No. 2. Page 6-28.

Kipnis, M. dan Hofstein, A. 2007. "The Inkuiry Laboratory As A Source for Development of Metacognitive Skills". International Journal of Science and Mathematic Education, Volume 6. Page 601-627.

Larkin, S. 2006."Collaborative Group Work and Individual Development of Metacognition in the Early Years".Research in Science Education. Volume 36 Page 7-27.

Liu, M., Horton, L., Olmanson, J., danToprac, P. 2011. "A Study of Learning and Motivation in a New Media Enriched Environment for Middle School Science". Education Tech Research Dev. Volume 1 No.59 Page 249-265.

Mambay, E.M. 2011. "Penerapan Pembelajaran Berbasis Masalah untuk Meningkatkan Penguasaan Konsep, Sikap Ilmiah, dan Kemampuan Bertanya Siswa SMA pada Topik Keanekaragaman Hayati”. Disertasi. Bandung: Sekolah Pascasarjana UPI.

Okoro, C. O. dan Chukwudi, E. K. 2011. "Metacognitive Strategies: A Viable Tool for Self-Directed Learning". Journal of Educational and Social Research, Volume 1 No. 4. Page 71-76.

Panaoura, A., dan Philippou, G. 2004. Young Pupils' Metacognitive Abilities in Mathematics in Relation to Working Memory and Processing Efficiency.http:// www.self.ox.ac.uk/Conferences/2004 Panaoura_Philippou.pdf (downloaded March 31 2013) 
Perfect, T. J. dan Schwartz, B. L. 2003. Applied Metacognition. Cambridge: Cambridge University Press.

Schneider , W. 2008. "The Development of Metacognitive Knowledge in Children and Adolescents: Major Trends and Implications for Education". Journal Compilation International Mind, Brain, and Education, Volume 2 No. 3. Page 114-121.

Shannon, S. V. dan College, W. S. 2008. "Using Metacognitive Strategies and Learning Styles to Create Self-Directed Learners". Institute for Learning Styles Journal, Volume 1, Fall 2008. Page 14-27.

Sugiyono. 2010. Metode Penelitian Pendidikan (Pendekatan Kuantitatif, Kualitatif, dan $R \& D)$. Bandung: Alfabeta.

Susantini, E. 2009. "Pengaruh Kemampuan Siswa Terhadap Perolehan Kognitif dan Metakognitif pada Pembelajaran Biologi”. Berk. Penel. Hayati Edisi Khusus. Volume 3E Hal 31-35.

Tan, O.S. 2004. Problem-based Learning: The Future Frontiers. http://www.tp.edu. sg/pbl._tan_oon_seng.pdf (downloaded March 3 2012).
Thomasa, G., Andersonb, D., dan Nashonb, S. 2008. "Development of an Instrument Designed to Investigate Elements of Science Students' Metacognition, SelfEfficacy and Learning Processes: The SEMLI-S”. International Journal of Science Education. Volume 30 No. 13. Page 1701-1724

Warouw Z. W. M. 2009. "Influence of the Metacognitive Learning in Cooperative Script and Reciprocal Teaching Strategies on Different Academic Capabilities toward Metacognitive Skill and Capability, Critical Thinking, Result of the Biology Learning, as well as Their Retentions at the State Junior High Schools in Manado". Disertasi. Malang: Program Pascasarjana Universitas Negeri Malang.

Woods, D. 2005. Problem-Based Learning, Especially in the Context of Large Classes. http://chemeng.mcmaster.ca/pbl/PBL. HTM (downloaded April 12 2012).

Zohar, A., dan Dori, Y. J. 2012. Metacognition in Science Education: Trends in Current Research. New York: Springer.

Zohar, A., dan Barzilai, S. 2013. "A Review of Research on Metacognition in Science Education: Current and Future Directions". Studies in Science Education. Volume 49 No 2, Page 121-169. 